\title{
ГЕОХИМИЯ ТЕРМАЛЬНЫХ ВОД И ФУМАРОЛЬНЫХ ГАЗОВ О. ШИАШКОТАН (КУРИЛЬСКИЕ ОСТРОВА)
}

\author{
(C) 2014 г. Е. Г. Калачева, Т. А. Котенко, Л. В. Котенко, Е. В. Волошина \\ Институт вулканологии и сейсмологии ДВО РАН \\ 683006 Петропавловск-Камчатский, бульвар Пийпа, 9, \\ e-mail:keg@kscnet.ru \\ Поступила в редакцию 24.04.2013 г.
}

\begin{abstract}
На основе геохимических исследований скорректированы представления об условиях формирования и разгрузки термальных вод о. Шиашкотан. Термальные источники, распространенные на острове, являются поверхностными проявлениями Северо-Шиашкотанской и Кунтоминтарской гидротермальных систем. Северо-Шиашкотанская гидротермальная система имеет классическую гидрохимическую зональность. Разгрузка Кунтоминтарской гидротермальной системы ограничена двумя термальными полями, расположенными в центральном и северо-восточном кратерах одноименного вулкана. Высокая температура газов вулкана Кунтоминтар на поверхности и повышенные прогностические отношения $\mathrm{S} / \mathrm{Cl}, \mathrm{S} / \mathrm{C}, \mathrm{CO}_{2} / \mathrm{H}_{2}$ в его составе свидетельствуют о возможной активизации его фумарольной деятельности.
\end{abstract}

DOI: $10.7868 / \mathrm{S} 0203030614050034$

Шиашкотан - один из островов Онекотанского блока Большой Курильской дуги (рис. 1) длиной 26 км. Основными морфологическими структурами острова являются два многоцентровых вулканических массива среднего плейстоценаголоцена [Стратула, 1969] Синарка и Кунтоминтар. В строении вулканических массивов отмечена [Мархинин, Стратула, 1966] смена вверх по разрезу примерно одинаковых комплексов пород, состоящих из переслаивающихся толщ лавовых и пирокластических потоков базальтового, андезибазальтового и андезитового составов. Фундамент четвертичных вулканов обнажается узкой полосой вдоль Тихоокеанского берега (см. рис. 1) и на перешейке Макарова, разделяющий остров на две части.

В истории формирования каждого из вулканов выделены три этапа. На начальном этапе были сформированы первые соммы вулканов. Второй этап завершился образованием вершинных эксплозивных кальдер. Активность вулкана Кунтоминтар в голоценовый период проявилась в возникновении нескольких кратеров в вершинной кальдере. С эксплозивной деятельностью одного из них связано возникновение пирокластического конуса, проявляющего в настоящее время активную фумарольную деятельность (см. рис. 1). В этот же период произошло образование котлови-

\footnotetext{
1 Стратула Д.С. Вулканы о. Шиашкотан и проблема вулканических рядов. Петропавловск-Камчатский. 1968. Фонды ИВиС ДВО РАН. 435 с.
}

ны-кальдеры в западной части постройки вулкана, в формировании которой, помимо ледниковой эрозии и вулкано-тектонических опусканий, существенную роль также сыграли направленные взрывы одного из кратеров вершинной кальдеры. На третьем этапе формирования вулкана Синарка в северо-восточной части кальдеры возник внутренний конус, частично разрушенный последующими направленными взрывами. Этап завершился выжиманием центрального экструзивного купола в 1987 г. [Горшков, 1967] и выбросами раскаленных лавин. Развитие четвертичного вулканизма о. Шиашкотан происходило на фоне интенсивных тектонических и вулкано-тектонических движений, фиксированных радиальными и секторными разломами (см. рис. 1), вдоль которых сосредоточена современная гидротермальная активность [Мархинин, Стратула, 1966].

На склонах вулканов и в береговой зоне разгружаются гидротермы различного химического состава и физико-химических показателей, которые детально исследовались в 1960-1970 гг. [Чирков и др., 1972; Мархинин, Стратула, 1977]. В этот же период Л.Н. Барабановым были выделены в пределах на острова две гидротермальные системы: Северо-Шиашкотанская и Кунтоминтарская, оценена их тепловая мощность. В 20072008 гг. были частично обследованы термальные

\footnotetext{
2 Барабанов Л.Н. Гидротермы Курильской вулканической области. Петропавловск-Камчатский. 1976. Т. 1. Фонды ИВИС ДВО РАН. 459 с.
} 

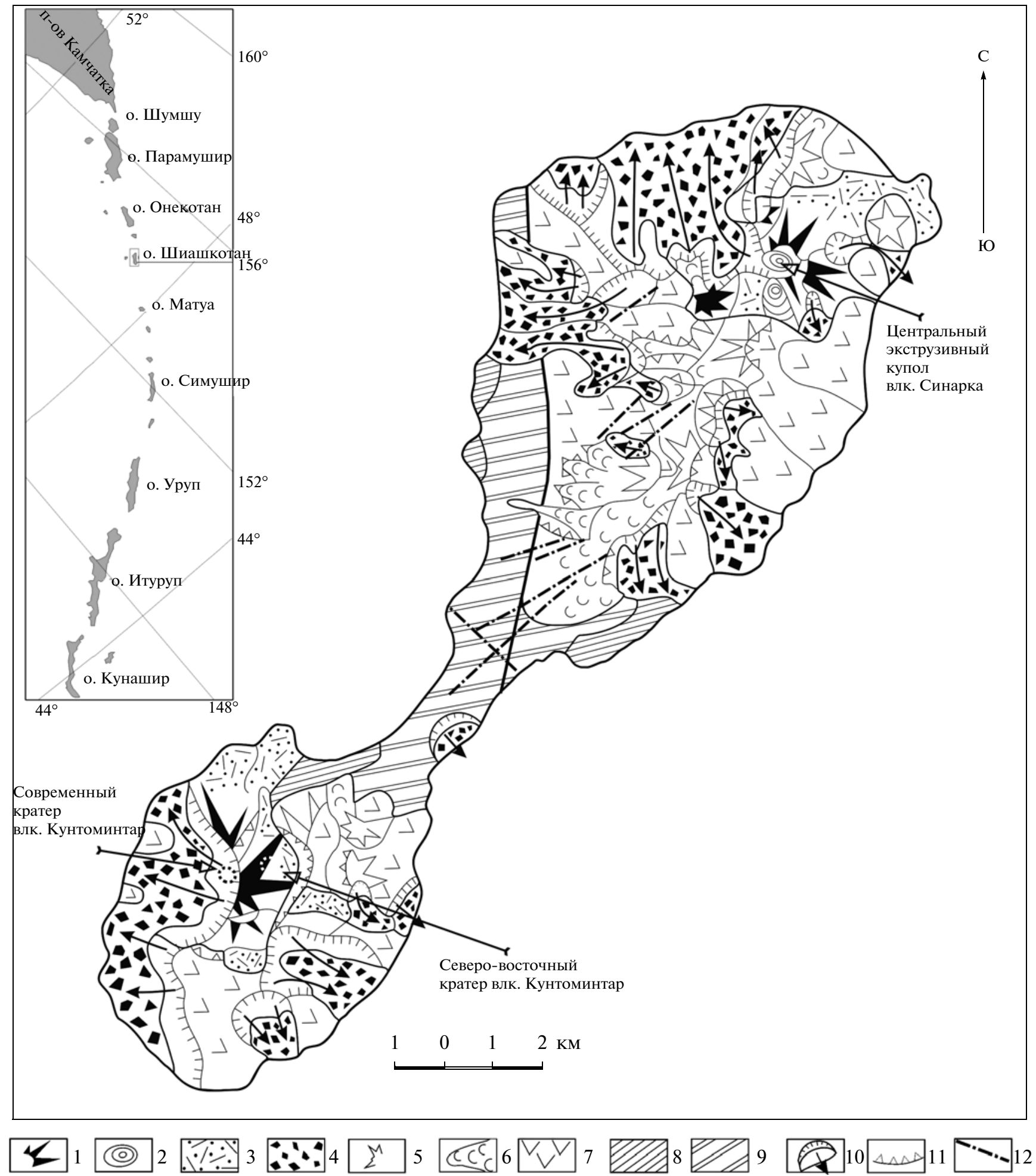

Рис. 1. Геолого-геоморфологическая карта-схема о. Шиашкотан (составлена по [Атлас..., 2007, Новейший..., 2005]). На врезке: расположение о. Шиашкотан в Курильской островной гряде по [Атлас..., 2007]).

Отложения голоценового возраста (андезиты): 1 - крупные вулканические постройки; 2 - экструзивные купола; 3 - пемзовые пирокластические покровы; 4 - обвально-осыпные отложения. Отложения позднеплейстоцен-голоценового возраста (базальт-андезитовые породы): 5 - фрагменты вулканических построек, выраженные в рельефе; 6 - лавовые потоки. Отложения средне-позднеплейстоценового возраста (андезиты, андезибазальты, базальты): 7 - фрагменты вулканических построек, не сохранившие первичного рельефа; 8 - абразионные морские террасы; 9 - вулканогенно-осадочные породы (туффиты, туфы и лавы от базальтового до андезитового состава) неогенового возраста; 10 - вулкано-сейсмотектонические обвалы; 11 - эрозионные уступы; 12 - разрывные нарушения, выраженные в рельефе. 
поля вулкана Синарка [Жарков и др., 2011]. В июне-июле 2011 года авторам удалось провести повторное опробование термальных источников острова и отобрать пробы газа в кратере вулкана Кунтоминтар.

Целью данной работы является: 1) описание термопроявлений острова по состоянию на 2011 г; 2) определение степени изменений на термальных плошадках, произошедших за последние 50 лет; 3) изучение геохимических особенностей термальных вод и газа; 4) рассмотрение условий формирования термальных вод.

\section{ИСХОДНЫЕ ДАННЫЕ И МЕТОДИКА РАБОТ}

Измерения физико-химических параметров вод термальных источников и речных вод (pH, $\mathrm{Eh}$, количество растворенных солей и температуpa, ${ }^{\circ}$ ) ) проводились непосредственно в точках отбора проб с помощью портативного анализатоpa Multi 340i/SET немецкой фирмы WTW. Для отделения растворенной части и тонких коллоидов от взвеси пробы воды отфильтровывались на месте отбора через мембранный фильтр $0.45 \mu$. Далее пробы помещались в специальную пластиковую тару объемом 0.5 л для проведения общего химического анализа.

Для забора фумарольных газов применялся барботажный жидкостный поглотительный метод отбора в вакуумированные барботеры емкостью 270-300 мл из кварцевого стекла с щелочным поглотителем (4M раствор КОН) [Никитина и др., 1989]. В работе применяли титановую газоотборную трубку. Конденсат фумарольного газа отбирался в сухой барботер с принудительной прокачкой газа и охлаждением стенок снегом.

Аналитические исследования выполнялись в Аналитическом центре ИВиС ДВО РАН (аналитики В.Н. Шапарь, И.Ф. Тимофеева, А.А. Кузьмина). Абсорбированные компоненты в пробах газа $\left(\mathrm{H}_{2} \mathrm{~S}, \mathrm{SO}_{2}, \mathrm{HCl}, \mathrm{CO}_{2}\right)$ определялись стандартными методами: потенциометрическим, иодометрическим, титрометрическим. Неабсорбированные газы $\left(\mathrm{H}_{2}, \mathrm{CO}, \mathrm{CH}_{4}, \mathrm{~N}_{2}, \mathrm{O}_{2}, \mathrm{Ar}, \mathrm{He}\right)$ определялись методом газовой хроматографии. Общий химический анализ водных проб, включающий определение ионов $\mathrm{Na}^{+}, \mathrm{K}^{+}, \mathrm{Ca}^{2+}, \mathrm{Mg}^{2+}, \mathrm{Al}^{3+}$, $\mathrm{Fe}^{3+}, \mathrm{Fe}^{2+}, \mathrm{HCO}_{3}^{-}, \mathrm{Cl}^{-}, \mathrm{F}^{-}, \mathrm{HSO}_{4}^{-}, \mathrm{SO}_{4}^{2-}, \mathrm{H}_{3} \mathrm{BO}_{3}$, $\mathrm{H}_{4} \mathrm{SiO}_{4}$, проводился потенциометрическим, объемным, колориметрическим методами.

Обработка гидрогеохимических данных, расчет глубинных температур на базе катионных геотермометров и графическое отображение химического состава термальных вод проводились с помощью компьютерной программы AQUACHEM 5.1 [AquaChim..., 2006]. Классификация вод основана на принципах, опубликованных IАН (Международная ассоциация гидрогеологов) [Inguaggiato et al.,
2000]. Общее количество катионов и анионов приведено к $100 \%$ и ионы, содержание которых в водной пробе больше $20 \%$, определяют тип вод.

\section{ТЕРМАЛЬНЫЕ ПОЛЯ И ИСТОЧНИКИ ОСТРОВА}

В пределах острова выделено [Мархинин, Стратула, 1977] девять групп термальных источников, три из которых (кратер вулкана Кунтоминтар, Центральный эффузивный купол и северо-восточный склон вулкана Синарка) приурочены к постройкам четвертичных вулканов (рис. 2). Остальные шесть групп располагаются в береговой зоне острова.

Термальные поля вулкана Кунтоминтар. Термопроявления сосредоточены в центральном и северо-восточном кратерах вулкана (см. рис. 2в). В центральном кратере они представлены многочисленными выходами парогазовых струй и термальными источниками, сформированными вдоль русла ручья Кратерного. Разделение донных фумарол на отдельные участки контролируется расчленением рельефа руслами ручьев, врезанными на глубину более 2 м. По состоянию на июнь-июль 2011 г. наблюдается следующая локализация групп парогазовых выходов. К удлиненному холму высотой 10-15 м, расположенному в центральной части дна кратера, приурочены более десяти мощных парогазовых струй со скоростью истечения на устье 15-20 м/с. Несмотря на то, что гребень и северный склон холма сложены серными отложениями, формирование серных конусов в местах выходов современных фумарол не происходит. Северная группа фумарол расположена в правом борту кратера и представляет собой одно большое термальное поле без крупных разгрузок. Южную группу фумарол, расположенную на склоне левого борта кратера, условно можно разделить на две подгруппы. Одна из них находится в нижней части склона, в состав ее входят четыре парогазовые струи. Другая подгруппа расположена на 60-70 м выше первой и представлена семью мощными выходами пара и газа. На дне кратера, в руслах временных водотоков расположены фумаролы F1-F4 (см. рис. 2). Эти парогазовые выходы сопровождаются обильным отложением серы, формирующей постройки разной формы. Температура газов фумарол F1-F4 не превышает $156^{\circ} \mathrm{C}$. Газы фумаролы F5, которая представляет собой обугленную трещину длиной 1.5 м, имеют температуру на выходе из устья $480^{\circ} \mathrm{C}$.

Выходы термальных вод сосредоточены вдоль ручья Кратерного, основного водотока центрального кратера. Всего было обнаружено [Мархинин, Стратула, 1977] около 20 однотипных выходов ультракислых (pH 1.5-1.9) высокотемпературных (до $80^{\circ} \mathrm{C}$ ) термальных вод с небольшими дебитами $(<0.3$ л/с) и минерализаций (далее М) 

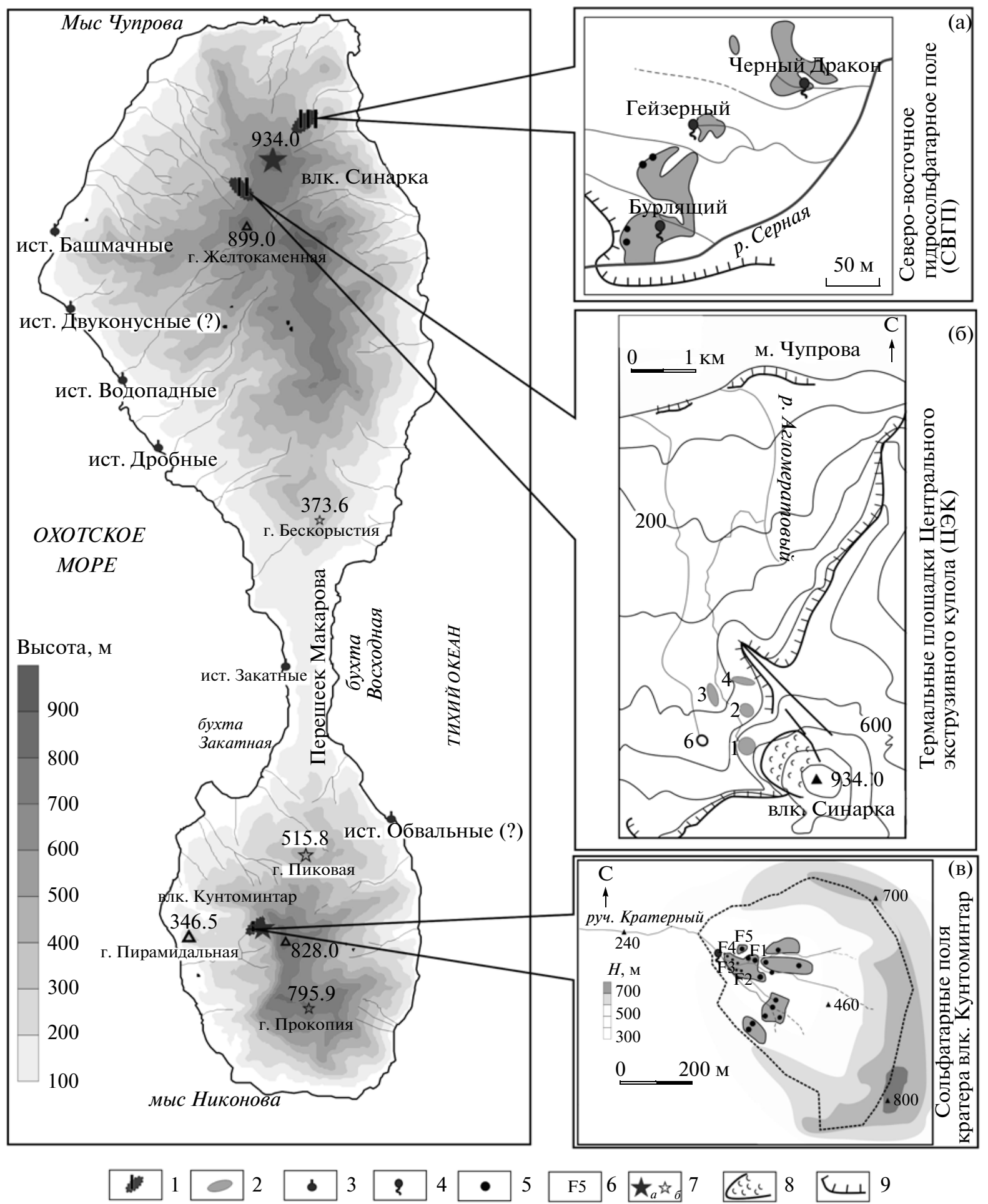

Рис. 2. Топографическая схема о. Шиашкотан и расположение термопроявлений.

1 - термальные поля: I - кратера влк. Кунтоминтар (в); II - Центрального экструзивного купола влк. Синарка (ЦЭК) (б); III - Северо-Восточное гидросольфатарное поле влк. Синарка (СВГП) (а) (схема по [Жарков и др., 2011]); 2 - термальные площадки; 3 - термальные источники прибрежной зоны; 4 - одиночные выходы термальных вод; 5 - парогазовые струи; 6 - номер фумаролы; 7 - вулканы: $a$ - действующий, $\sigma$ - потухший; 8 - лавовый поток экструзивного купола влк. Синарка; 9 - эрозионные уступы. 
до 7.7 г/л. Один из источников дебитом 0.5 л/с, расположенный на левом берегу ручья Кратерного (см. рис. 2), был опробован авторами (табл. 1). Температура его составляет $64^{\circ} \mathrm{C}, \mathrm{pH}=$ $=2.16, \mathrm{Eh}+311$ мВ при минерализации 5.4 г/л. Термальная вода поступает в русло ручья Кратерного. На выходе из кратера расход ручья равен 4 л/с, температура воды составляет $18.4^{\circ} \mathrm{C}$, $\mathrm{pH}=2.42, \mathrm{Eh}+265 \mathrm{mB}$.

По химическому составу термальные воды кратера вулкана Кунтоминтар и воды ручья Кратерного, опробованные ниже термальных полей, относятся K $\mathrm{Al}-\mathrm{Ca}-\mathrm{SO}_{4}$ типу вод (см. табл. 1) с высокими значениями $\mathrm{Fe}^{3+}$ (до 195 мг/л). Конденсат фумарольных газов в кратере вулкана Кунтоминтар по составу резко отличается от состава терм и соответствует $\mathrm{Ca}-\mathrm{Cl}$ гидрохимическому типу с $\mathrm{M}=1.3$ г/л. В конденсате определено наибольшее среди опробованных водопроявлений

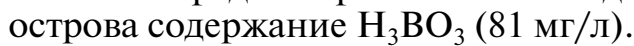

Северо-восточный кратер вулкана Кунтоминтар (см. рис. 1) имеет форму амфитеатра диаметром 300 м, открытого на север крупным оврагом с высотой стенок до 100 м. Дно прорезает узкое русло ручья. В литературе нет упоминаний о термальной активности в этом кратере. Во время полевых работ на северо-западном склоне на 50 м выше дна, что составляет около 400 м над уровнем моря, авторами обнаружены две фумаролы. Скорость верхней, более сильной, струи по визуальной оценке не более 10 м/с. Выходы фумарол трассирует трещина. Подойти к фумаролам не удалось из-за большой крутизны и глубины ущелья. Согласно геолого-геоморфологической карте-схеме (см. рис. 1) оба участка термальных проявлений расположены на границе вершинной кальдеры. Центральный кратер фиксирует пересечение ее границы с границей котловины-кальдеры второй соммы вулкана Кунтоминтар.

Термальные площадки склонов вулкана Синарка. Горячие источники, приуроченные к Центральному экструзивному куполу (далее ЦЭК), распроложены на западном склоне вулкана ниже подножия купола. Ранее [Мархинин, Стратула, 1977] здесь было обнаружено шесть термальных площадок. В июле 2011 г. они были обследованы авторами статьи.

Термальные площадки 1-3 находятся по бортам различной крутизны (от 5-6 $6^{\circ}$ до $40^{\circ}$ ) в верховьях ручья Агломератового. Площадка 1 (см. рис. 2б) находится у подножия экструзивного купола на высоте 500 м над уровнем моря в полосе размером $20 \times 50$ м. В 250-300 м к северо-востоку от нее на правом пологом борту промоины глубиной около 10 м расположена площадка 2. Ниже по течению, на левом крутом склоне ручья Агломератового находится площадка 3. Все термальные участки покрыты плащами гидроокислов железа мощностью от 1 до 10 см. Сквозь небольшие проколы в плаще под напором вытекает вода, иногда образуя фонтанчики высотой до 10 см. Русла термальных ручейков покрыты термофильными водорослями ярко-зеленого цвета. Температура вод, разгружающихся на площадках, составляет $37-52^{\circ} \mathrm{C}$, значения рН варьируют от 2.6 до 3.2, диапазон Eh составляет $+230 \ldots+270 \mathrm{MB}$, электропроводность варьирует от 4100 до $8040 \mu \mathrm{S} / \mathrm{cm}$. Дебит ручья Агломератового, в русло которого стекает термальная вода ниже площадки 3, составляет 15 л/с при температуре $21.3^{\circ} \mathrm{C}$, pH 3.38, Eh $+211 \mathrm{mB}$.

Термальные источники ЦЭК вулкана Синарка имеют пестрый состав, среди катионов преобладают $\mathrm{Ca}^{2+}, \mathrm{Mg}^{2+}$ и $\mathrm{Al}^{3+}$, среди анионов $\mathrm{Cl}^{-}$и $\mathrm{SO}_{4}^{2-}$ (см. табл. 1). Минерализация изменяется от 4.2 до 6.2 г/л. Максимальное содержание растворенной кремнекислоты в 459 мг/л наблюдается в пробе, отобранной на площадке 1. Для этой пробы также характерны наибольшие концентрации $\mathrm{Cl}^{-}$(2.5 г/л), $\mathrm{Na}^{+}$(385 мг/л), $\mathrm{Mg}^{2+}$ (501 мг/л) $\mathrm{Fe}^{3+}$ (106 мг/л) и $\mathrm{H}_{3} \mathrm{BO}_{3}$ (49 мг/л). Химический состав вод ручья Агломератового ниже термальных площадок аналогичен составу термальных вод (см. табл. 1) при меньшей минерализации - 2.3 г/л.

Согласно описанию, приведенному в работе [Мархинин, Стратула, 1977], площадка 4 расположена в распадке, берущем начало у подножия экструзивного купола, выжатого несколько севернее ЦЭК (см. рис. 2б). Авторам побывать на ней не удалось. Химический состав термальных вод площадки по [Мархинин, Стратула, 1977] представлен в табл. 1 .

Термальная площадка 5, описанная в [Мархинин, Стратула, 1977], авторами не обнаружена. Площадка 6, расположенная в 200-250 м к западу от водопроявлений первого участка на склонах циркообразной впадины глубиной 10 м и диаметром 20 м, сохранилась, однако термопроявлений на ней нет. Все рассредоточенные нисходящие источники, разгружающиеся в этом месте, имеют температуру $5-6^{\circ} \mathrm{C}$, слабо кислую реакцию $(\mathrm{pH}=4.7)$ и общий дебит 8-10 л/с.

Северо-восточное гидросольфатарное поле вулкана Синарка (далее СВГП) (см. рис. 2а) авторам посетить не удалось. В работе использованы данные о расположении термопроявлений и химические параметры термальных вод (см. табл. 1), приведенные в работах [Мархинин, Стратула, 1977; Жарков и др., 2011].

Источники прибрежной зоны. Как отмечалось выше, в прибрежной полосе острова выделено [Мархинин, Стратула, 1977] шесть групп термопроявлений (Башмачная, Двуконусная, Водопадная, Дробная, Закатная, Обвальная) (см. рис. 2) с суммарным дебитом всех источников 50 л/с. Авторами было обследовано 5 из них (кроме Башмачной группы). Видимых изменений на площадках, где расположены источники Водопадной, Дробной и Закатной групп, по сравнению с 
ранее представленном описанием [Мархинин, Стратула, 1977], не произошло. В местах предположительного нахождения Двуконусных источников и источников мыса Обвального (см. рис. 2) выходов подземных вод (холодных или термальных) не обнаружено.

Условия разгрузки источников Водопадных, Дробных и Закатных (см. рис. 2) очень схожи. Выходы термальных вод приурочены к дайковым комплексам. В зависимости от строения береговой линии разгрузка термальных вод осуществляется по трещинам в лавах (источники Дробные), со дна лунок между пляжными валунами (источники Водопадные) или из песчаных пляжных отложений (источники Закатные). Большинство из них находятся в приливно-отливной полосе и обнажаются только во время отливов. Средняя протяженность выходов вдоль берега составляет от 100 до 225 м. Дебиты отдельных выходов не превышают 0.2-0.3 л/с. Максимальная температура воды $63.8^{\circ} \mathrm{C}$ измерена в источниках Водопадной группы. Все они характеризуются близнейтральной реакцией (рH = 5.9-6.9). Изредка в местах выходов источников пробулькивают пузырьки газа с дебитом отдельных газовых струй до 1.5 л/ч (источники Закатные). Водопроводящие трещины заполнены сцементированным мелкоземом, иногда полосчатым халцедоном, кальцитом и пиритом.

Химический состав термальных вод прибрежной зоны, включая опубликованные данные по Башмачной группе источников, приведены в таблице 1. Термальные воды относятся к $\mathrm{Na}-\mathrm{Cl}$ типу (см. табл. 1) с минерализацией от 3.1 до 12.9 г/л. Для них характерны также высокие значения электропроводности от 8310 до $18260 \mu \mathrm{S} / \mathrm{cм}$. Концентрация растворенной $\mathrm{H}_{4} \mathrm{SiO}_{4}$ колеблется от 110 до 280 мг/л, среднее содержание $\mathrm{H}_{3} \mathrm{BO}_{3}$ составляет 40 мг/л. Количество растворенного железа в водах источников прибрежной зоны ниже предела обнаружения, однако практически все выходы сопровождаются охристыми налетами и натеками его гидроокислов.

\section{РЕЗУЛЬТАТЫ И ОБСУЖДЕНИЯ}

Геохимия газов. Газ и конденсат, представленные в табл. 2, отбирались из фумаролы F5 вулкана Кунтоминтар 24.06.2011. Для рассмотрения происхождения фумарольного газа были построены тройные диаграммы относительного содержания (мол. \%) $\mathrm{CO}_{2}-\mathrm{HCl}-\left(\mathrm{H}_{2} \mathrm{~S}+\mathrm{SO}_{2}\right)$ (рис. 3a) и $\mathrm{N}_{2}-\mathrm{Ar}-\mathrm{He}$ (см. рис. 3б). Для сравнительной характеристики полученных результатов в построении диаграмм использованы данные по низко- и среднетемпературным газам вулкана Эбеко [Котенко и др., 2012] и высокотемпературным газам андезитовых вулканов [Shinohara et al., 1993].
Несмотря на достаточно высокую температуру газов вулкана Кунтоминтар, их компонентный состав отличен от высокотемпературных газов андезитовых вулканов (см. рис. 3а). Для них наблюдаются более высокие относительные содержания газов серы и хлора. Наиболее близки по составу к газам вулкана Кунтоминтар высокообводненные фумаролы, расположенные в кратерах вулканов Эбеко и Белый остров.

Для оценки генезиса газов фумарол мы исследовали содержания в них $\mathrm{N}_{2}$, Ar и Не. Точки, отражающие состав газовых проб, вынесенные на тройную диаграмму относительного содержания (мол. \%) $\mathrm{N}_{2}-\mathrm{Ar}-\mathrm{He}$ (см. рис. 3б), расположены вблизи линии $\mathrm{N}_{2}-\mathrm{Ar}$ в области отношений, характерных для воздуха или метеорных вод, насыщенных воздухом. В отличие от газов вулкана Эбеко и высокотемпературных газов андезитовых вулканов Японии, здесь не наблюдается тренд ни к первичному вулканическому газу, ни к субдукционной компоненте. Отношение $\mathrm{N}_{2} / \mathrm{O}_{2}=4.5$ несколько выше воздушного, что характерно для окислительных обстановок (небольшой дефицит кислорода по отношению к азоту).

Результирующий состав газа на поверхности является функцией скорости подъема летучих компонентов и условий, встреченных на пути миграции. Для анализа этих условий рассматриваются окислительно-восстановительные условия и формы существования элементов с переменной валентностью (например, $\mathrm{H}_{2} / \mathrm{H}_{2} \mathrm{O}, \mathrm{CH}_{4} / \mathrm{CO} / \mathrm{CO}_{2}$ ) (рис. 4). Предполагаемые траектории остывания традиционно изображаются в координатной сетке: редокс-отношения для газов $(\lg f)-\mathrm{T},{ }^{\circ} \mathrm{C}-$ линии равновесных минеральных реакций (породные буферы) [Giggenbach et al., 1990]. Редокс-отношения для пары $\mathrm{CO} / \mathrm{CO}_{2}$ (рис. 5a) контролируются соперничеством газового буфера и НМ буфера, что характерно для гидротермальных условий. На диаграмме редокс-отношений для Н2/H2O (см. рис. 5б) положение точек вулкана Кунтоминтар предполагает наличие преимущественно жидкой гидротермальной системы [Giggenbach, 1997], когда при поглощении магматических летучих компонентов подземными водами, происходит образование очень агрессивных растворов.

Для расчета теплового потока, выносимого газами, была использован номограмма Федотова [Федотов, 1982] и наблюдения за высотой подъема фумарольных струй из кратера. По нашим данным он составил, в среднем, 40 МВт. Тепловая мощность парогазовых струй в 1970 г. оценивалась величиной 12 МВт $^{2}$. Разница полученных величин может быть связана не столько с процессом усиления теплового потока, сколько с разными методиками его оценки. 


\begin{tabular}{|c|c|c|c|c|c|c|c|c|c|c|c|c|c|c|c|c|c|c|c|c|c|c|}
\hline$\stackrel{\bigcup}{I}^{1}=$ & & & & $\stackrel{\infty}{\infty}$ & $\begin{array}{l}\stackrel{N}{\dot{n}} \\
\stackrel{\Omega}{\Omega}\end{array}$ & $\stackrel{\circ}{9}$ & $\frac{n}{a}$ & & & & & & $\begin{array}{l}\dot{d} \\
\stackrel{m}{m}\end{array}$ & 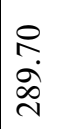 & $\begin{array}{l}8 \\
\stackrel{1}{1} \\
\Xi\end{array}$ & 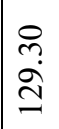 & 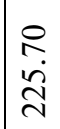 & $\begin{array}{l}\dot{8} \\
\dot{0} \\
\dot{\sim}\end{array}$ & $\begin{array}{l} \pm \\
\stackrel{\Xi}{0}\end{array}$ & $\begin{array}{l}\stackrel{n}{n} \\
\infty \\
\infty\end{array}$ & & $\begin{array}{l}\text { ते } \\
\dot{m}\end{array}$ \\
\hline$\frac{1}{U} \stackrel{5}{\xi}$ & $\stackrel{\stackrel{+}{i}}{\stackrel{m}{m}}$ & $\frac{n}{0}$ & $\begin{array}{l}n \\
\infty \\
\infty \\
\infty\end{array}$ & $\begin{array}{l}\infty \\
\dot{a} \\
\dot{a}\end{array}$ & $\begin{array}{l}\hat{\sigma} \\
\infty \\
0\end{array}$ & $\frac{n}{\dot{q}}$ & $\begin{array}{l}0 \\
\dot{\leftrightarrow} \\
\dot{\imath}\end{array}$ & $\begin{array}{l}0 \\
\stackrel{0}{0} \\
\widetilde{\sigma}\end{array}$ & 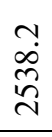 & $\begin{array}{l}0 \\
\dot{b} \\
0\end{array}$ & $\begin{array}{l}n \\
\stackrel{n}{+} \\
\infty \\
n\end{array}$ & 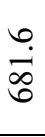 & 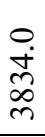 & 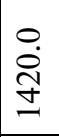 & $\begin{array}{l}0 \\
\hat{n} \\
\vdots \\
+ \\
+\end{array}$ & $\begin{array}{l}0 \\
\dot{0} \\
\infty \\
\stackrel{\gamma}{\gamma}\end{array}$ & $\begin{array}{l}0 \\
0 \\
0 \\
6 \\
6\end{array}$ & 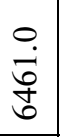 & 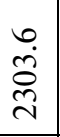 & $\begin{array}{l}n \\
n \\
\infty \\
\infty \\
m\end{array}$ & $\overline{\mathrm{i}}$ & \\
\hline$\stackrel{5}{5}$ & $\begin{array}{l}\vec{\nabla} \\
\dot{n}\end{array}$ & $\begin{array}{l}\text { fr. } \\
\dot{r}\end{array}$ & in & $\stackrel{g}{\stackrel{g}{+}}$ & $\stackrel{\partial}{\text { oे }}$ & $\begin{array}{l}m \\
\infty \\
0 \\
0\end{array}$ & $\stackrel{ \pm}{\stackrel{m}{-}}$ & 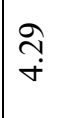 & તું & $\stackrel{\sim}{\stackrel{+}{+}}$ & $\stackrel{\nabla}{\sim}$ & 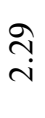 & 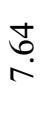 & $\begin{array}{l}8 \\
\dot{m}\end{array}$ & $\begin{array}{l}\vec{D} \\
\infty \\
\infty\end{array}$ & $\begin{array}{l}\hat{\sigma} \\
\infty\end{array}$ & $\begin{array}{l}\infty \\
\infty \\
\end{array}$ & 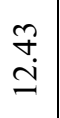 & $\ddot{m}$ & 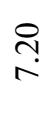 & $\approx$ & \\
\hline $\begin{array}{l}0^{m} \\
\overbrace{}^{m} \\
I^{m}\end{array}$ & $\underset{i}{\stackrel{i}{i}}$ & $\begin{array}{l}\infty \\
\infty \\
\stackrel{0}{0}\end{array}$ & $\begin{array}{l}\hat{\alpha} \\
\dot{\infty}\end{array}$ & ڤิ & $\begin{array}{l}\widehat{8} \\
\dot{0}\end{array}$ & $\begin{array}{l}\widehat{\Xi} \\
\stackrel{ \pm}{ \pm}\end{array}$ & I & 1 & $\begin{array}{l}\stackrel{2}{\circ} \\
\infty \\
+\end{array}$ & $\begin{array}{l}\infty \\
\infty \\
\ddot{n}\end{array}$ & $\stackrel{?}{\stackrel{\sim}{\sim}}$ & ঙे & 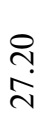 & 文 & $\begin{array}{l}\stackrel{\infty}{i} \\
\ddot{b}\end{array}$ & $\begin{array}{l}\stackrel{0}{n} \\
\text { }\end{array}$ & $\begin{array}{l}0 \\
\stackrel{q}{\mathcal{I}}\end{array}$ & 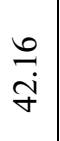 & 1 & 1 & & \\
\hline 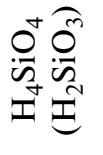 & $\begin{array}{l}\stackrel{\Omega}{\circ} \\
\infty \\
\stackrel{\infty}{二}\end{array}$ & $\begin{array}{l}\infty \\
\infty \\
\dot{0} \\
i\end{array}$ & సָ & 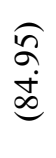 & $\begin{array}{l}\overparen{\widetilde{n}} \\
\stackrel{\sigma}{6}\end{array}$ & 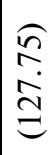 & $\begin{array}{l}\widehat{\Xi} \\
\dot{0} \\
\stackrel{0}{\Xi}\end{array}$ & $\begin{array}{l}\hat{\Xi} \\
\stackrel{8}{0} \\
\triangleq\end{array}$ & $\begin{array}{l}\infty \\
\infty \\
\dot{\circ} \\
\qquad\end{array}$ & $\begin{array}{l}\dot{8} \\
\dot{m} \\
\frac{m}{m}\end{array}$ & $\begin{array}{l}8 \\
\stackrel{i}{2} \\
\grave{i}\end{array}$ & $\begin{array}{c}\text { ָ̦ } \\
\text { }\end{array}$ & 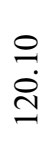 & $\stackrel{\infty}{\infty}$ & $\begin{array}{l}\text { \&े } \\
\stackrel{+}{0} \\
\text { dे }\end{array}$ & $\begin{array}{l}\text { f } \\
\text { oे } \\
\text { oे }\end{array}$ & $\stackrel{?}{\stackrel{2}{\dot{d}}}$ & $\begin{array}{l}\stackrel{\overbrace{}}{\sim} \\
\stackrel{\sim}{\sim}\end{array}$ & 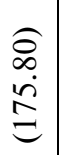 & $\begin{array}{l}\text { oे } \\
+ \\
\dot{5} \\
\text { d }\end{array}$ & $\hat{\sigma}$ & \\
\hline 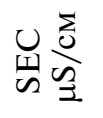 & 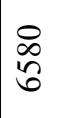 & $\underset{\substack{\infty \\
m}}{ }$ & $\begin{array}{l}\stackrel{8}{\circ} \\
\stackrel{0}{0}\end{array}$ & $\stackrel{\circ}{x}$ & $\stackrel{\circ}{9}$ & $\stackrel{0}{x}$ & $\stackrel{0}{9}$ & $\stackrel{\circ}{9}$ & $\underset{\infty}{\stackrel{+}{\circ}}$ & $\frac{0}{6}$ & 点 & & $\begin{array}{l}\stackrel{8}{8} \\
\stackrel{-}{1}\end{array}$ & $\frac{0}{\infty}$ & $\begin{array}{l}0 \\
\stackrel{0}{ } \\
\stackrel{0}{\simeq}\end{array}$ & $\begin{array}{l}8 \\
0 \\
0 \\
\end{array}$ & 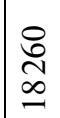 & $\begin{array}{l}\stackrel{8}{2} \\
I\end{array}$ & $\stackrel{\circ}{3}$ & $\stackrel{\circ}{9}$ & $\underset{m}{\infty}$ & \\
\hline 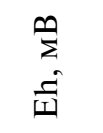 & $\stackrel{\sim}{\sim}$ & $\bar{m}$ & $\stackrel{\circ}{m}$ & $\stackrel{\circ}{9}$ & $\frac{0}{1}$ & $\stackrel{\circ}{9}$ & $\stackrel{\circ}{I}$ & $\stackrel{\circ}{x}$ & $\stackrel{\widehat{\vartheta}}{ }$ & $\underset{\sim}{\sim}$ & $\vec{\sim}$ & $\bar{\sim}$ & กี & $\hat{\sigma}$ & $a$ & 字 & 于 & $\vec{\sim}$ & $\stackrel{\circ}{9}$ & $\stackrel{0}{9}$ & $\stackrel{ \pm}{\Xi}$ & \\
\hline 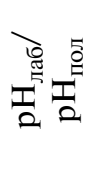 & 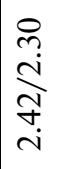 & 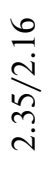 & 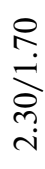 & $\begin{array}{l}\text { Oे } \\
\dot{+}\end{array}$ & ठ̊. & $\begin{array}{l}\stackrel{े}{े} \\
\dot{m}\end{array}$ & $\frac{\partial}{2}$ & $\begin{array}{l}\partial \\
\infty \\
i\end{array}$ & 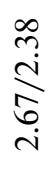 & 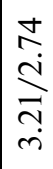 & $\begin{array}{l}8 \\
\dot{\delta} \\
\dot{\delta} \\
\dot{\delta} \\
\dot{r}\end{array}$ & $\alpha$ & 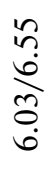 & 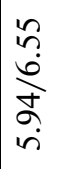 & $\begin{array}{l}+ \\
0 \\
5 \\
\infty \\
\infty \\
0 \\
0\end{array}$ & 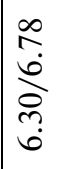 & 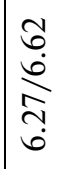 & 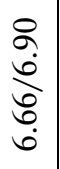 & $\vec{b}$ & ते & 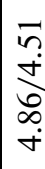 & \\
\hline $0_{0}^{0}$ & $\stackrel{\vec{\infty}}{\stackrel{\infty}{-}}$ & $\begin{array}{l}n \\
\dot{J}\end{array}$ & & ì. & $\alpha$ & : & $\vec{\sigma}$ & $\vec{\infty}$ & $\frac{n}{n}$ & $\begin{array}{l}\stackrel{0}{0} \\
\text { m. }\end{array}$ & $\begin{array}{l}\text { ì } \\
\stackrel{\gamma}{ }\end{array}$ & & nin & @िं. & $\begin{array}{l}0 \\
\text { in }\end{array}$ & ڤ. & $\stackrel{\dot{p}}{\dot{q}}$ & $\begin{array}{l}\stackrel{\nabla}{\tilde{\sigma}} \\
\stackrel{\nabla}{*}\end{array}$ & $\begin{array}{l}\stackrel{\circ}{\mathbb{D}} \\
\stackrel{2}{2}\end{array}$ & $\stackrel{0}{r}$ & in & \\
\hline
\end{tabular}




\begin{tabular}{|c|c|c|c|c|c|c|c|c|c|c|c|c|c|c|c|c|c|c|c|c|c|c|}
\hline 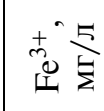 & $\begin{array}{l}\stackrel{0}{n} \\
\stackrel{2}{2} \\
\approx\end{array}$ & 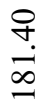 & & 1 & $\stackrel{n}{n}$ & $\underset{i}{\stackrel{8}{i}}$ & $\stackrel{0}{\circ}$ & $\begin{array}{l}8 \\
\dot{0} \\
\infty\end{array}$ & $\begin{array}{l}\tilde{\delta} \\
\dot{\delta} \\
\varrho\end{array}$ & $\begin{array}{l}\stackrel{\varrho}{ \pm} \\
\dot{ \pm}\end{array}$ & $\begin{array}{l}8 \\
0 \\
0 \\
0\end{array}$ & 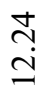 & $\begin{array}{l}n \\
\dot{\theta} \\
\dot{v}\end{array}$ & $\begin{array}{l}n \\
\hat{\dot{p}} \\
\dot{v}\end{array}$ & 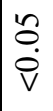 & $\stackrel{n}{o}$ & $\begin{array}{l}n \\
\dot{\dot{p}} \\
\dot{v}\end{array}$ & $\begin{array}{l}n \\
\stackrel{2}{\dot{p}} \\
\dot{v}\end{array}$ & $\stackrel{\circ}{3}$ & $\stackrel{\circ}{\stackrel{2}{x}}$ & $\begin{array}{l}\stackrel{n}{0} \\
\dot{\theta}\end{array}$ & $\stackrel{\circ}{9}$ \\
\hline & $\begin{array}{l}\stackrel{n}{n} \\
n \\
n \\
n\end{array}$ & 号 & & 1 & 1 & 1 & 1 & $\begin{array}{l}8 \\
0 \\
i \\
\text { in }\end{array}$ & $\frac{\vec{J}}{\vec{g}}$ & $\begin{array}{l}\infty \\
\infty \\
\end{array}$ & $\begin{array}{l}\tilde{n} \\
\tilde{\gamma}\end{array}$ & $\begin{array}{l}\tilde{\sim} \\
\text { ָे }\end{array}$ & $\begin{array}{l}0 \\
\tilde{j} \\
\dot{\hat{v}}\end{array}$ & $\begin{array}{l}\dot{0} \\
\tilde{\imath} \\
\dot{v}\end{array}$ & 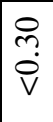 & 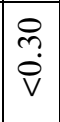 & $\begin{array}{l}0 \\
\tilde{v} \\
\dot{\hat{v}}\end{array}$ & $\begin{array}{l}\stackrel{\ominus}{0} \\
\dot{\theta} \\
\dot{v}\end{array}$ & $\stackrel{0}{1}$ & $\stackrel{\circ}{1}$ & $\begin{array}{l}\text { गे. } \\
\dot{\hat{v}}\end{array}$ & $\stackrel{0}{\geq}$ \\
\hline & $\stackrel{\circ}{3}$ & $\begin{array}{l}n \\
\stackrel{0}{0} \\
v\end{array}$ & & 1 & 1 & in & $\begin{array}{l}\infty \\
\infty \\
0\end{array}$ & $\stackrel{0}{0}$ & $\begin{array}{l}n \\
\dot{\vec{p}} \\
\dot{v}\end{array}$ & $\begin{array}{l}n \\
\ddot{\dot{\theta}} \\
\mathrm{v}\end{array}$ & $\mid \begin{array}{l}n \\
\dot{q} \\
\dot{v}\end{array}$ & $\stackrel{n}{\hat{\theta}}$ & $\begin{array}{l}n \\
\ddot{\dot{\theta}} \\
\dot{v}\end{array}$ & $\begin{array}{l}n \\
\dot{\vec{v}} \\
\dot{v}\end{array}$ & 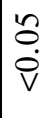 & $\begin{array}{l}n \\
\stackrel{\theta}{\dot{v}} \\
\mathrm{v}\end{array}$ & $\begin{array}{l}n \\
\dot{\dot{\theta}} \\
\dot{v}\end{array}$ & $\begin{array}{l}\ddot{\partial} \\
\dot{\vec{v}} \\
\mathrm{v}\end{array}$ & $\frac{0}{3}$ & $\stackrel{\circ}{x}$ & $\stackrel{n}{\dot{\theta}}$ & $\stackrel{\circ}{\grave{1}}$ \\
\hline & 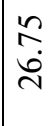 & $\begin{array}{l}\text { సे. } \\
\text { సे }\end{array}$ & . & $\begin{array}{l}\vec{b} \\
\dot{q}\end{array}$ & 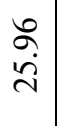 & $\begin{array}{l}0 \\
\infty \\
\infty \\
\infty \\
-1\end{array}$ & $\begin{array}{l}q \\
\dot{q} \\
\dot{f}\end{array}$ & $\begin{array}{l}8 \\
\text { \& } \\
\dot{\Phi} \\
\text { D }\end{array}$ & $\begin{array}{l}8 \\
\dot{8} \\
\dot{8}\end{array}$ & $\begin{array}{c}\infty \\
\tilde{n} \\
\infty \\
\tilde{N} \\
\end{array}$ & $\begin{array}{l}8 \\
\infty \\
\infty \\
\tilde{m}\end{array}$ & $\begin{array}{l}\stackrel{0}{1} \\
\text { } \\
\end{array}$ & 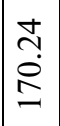 & $\begin{array}{l}\infty \\
\infty \\
\dot{m} \\
m\end{array}$ & 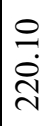 & 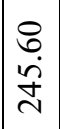 & $\begin{array}{l}8 \\
\dot{+} \\
\dot{\vec{m}}\end{array}$ & 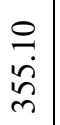 & $\begin{array}{l}2 \\
0 \\
\infty\end{array}$ & $\frac{8}{\dot{a}}$ & $\stackrel{\sim}{\stackrel{\vec{v}}{v}}$ & ڤิ \\
\hline & $\begin{array}{l}\stackrel{\infty}{\mathcal{I}} \\
\underset{\forall}{\sigma}\end{array}$ & f & $\stackrel{0}{\circ}$ & $\stackrel{\stackrel{+}{I}}{\underline{I}}$ & $\begin{array}{l}0 \\
\grave{\Xi} \\
ٍ\end{array}$ & $\stackrel{\bullet}{\stackrel{0}{R}}$ & $\frac{O}{i}$ & $\begin{array}{l}0 \\
\dot{0} \\
\tilde{n}\end{array}$ & $\begin{array}{l}\overrightarrow{3} \\
\dot{m} \\
\dot{n}\end{array}$ & $\mid \frac{\dot{m}}{\vec{n}}$ & $\begin{array}{l}\stackrel{0}{a} \\
\stackrel{\circ}{\sigma}\end{array}$ & $\stackrel{n}{\stackrel{n}{N}}$ & $\begin{array}{l}1 \\
\dot{\infty} \\
\infty\end{array}$ & $\begin{array}{l}n \\
\stackrel{2}{n} \\
n\end{array}$ & $\begin{array}{l}\text { ?ִ } \\
\stackrel{+}{N}\end{array}$ & 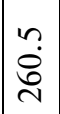 & 吕 & $\begin{array}{l}n \\
\stackrel{n}{+} \\
\stackrel{+}{v}\end{array}$ & $\begin{array}{l}\stackrel{\dot{j}}{i} \\
\stackrel{\dot{\sim}}{\sim}\end{array}$ & 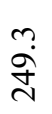 & $\stackrel{\infty}{0}$ & वे. \\
\hline+ & $\stackrel{2}{\sigma}$ & $\stackrel{2}{2}$ & $?$ & $\begin{array}{l}\text { जे } \\
\text { in }\end{array}$ & $\stackrel{8}{\circ}$ & & $\begin{array}{l}\stackrel{8}{0} \\
\text { İ }\end{array}$ & $\stackrel{\overbrace{}}{\stackrel{\text { I }}{=}}$ & $\begin{array}{l}\infty \\
\infty \\
\grave{\lambda}\end{array}$ & $\begin{array}{l}0 \\
n \\
0 \\
0\end{array}$ & 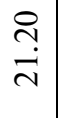 & $\stackrel{\varrho}{\stackrel{+}{+}}$ & $\begin{array}{l}\stackrel{+}{+} \\
\stackrel{2}{a} \\
\stackrel{2}{2}\end{array}$ & $\begin{array}{l}\infty \\
\infty \\
\infty \\
\infty \\
n\end{array}$ & $\begin{array}{l}\stackrel{ }{\mathcal{O}} \\
\stackrel{ \pm}{\Xi}\end{array}$ & 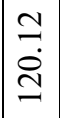 & 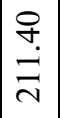 & 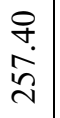 & $\begin{array}{l}\stackrel{8}{2} \\
\stackrel{2}{2}\end{array}$ & & $\stackrel{⿱ 亠 凶}{i}$ & \\
\hline
\end{tabular}

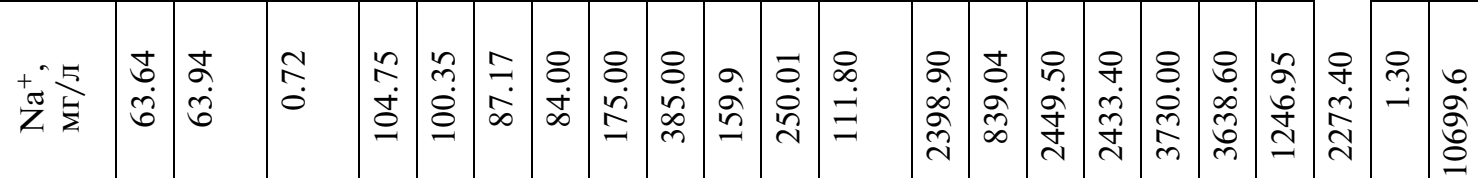

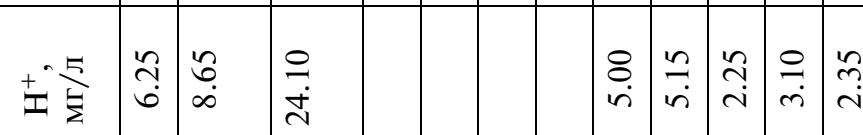

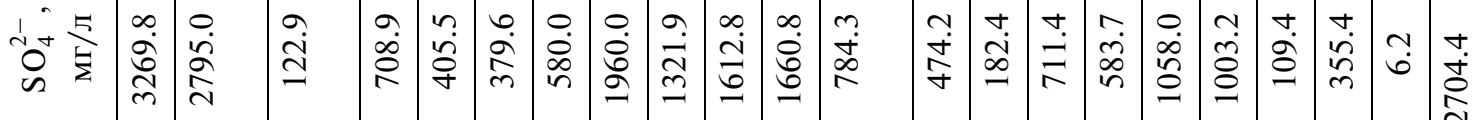

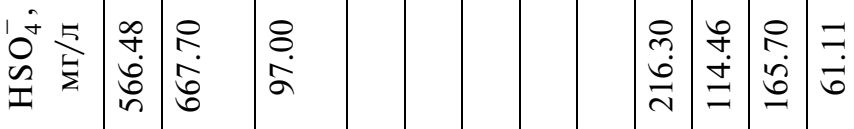

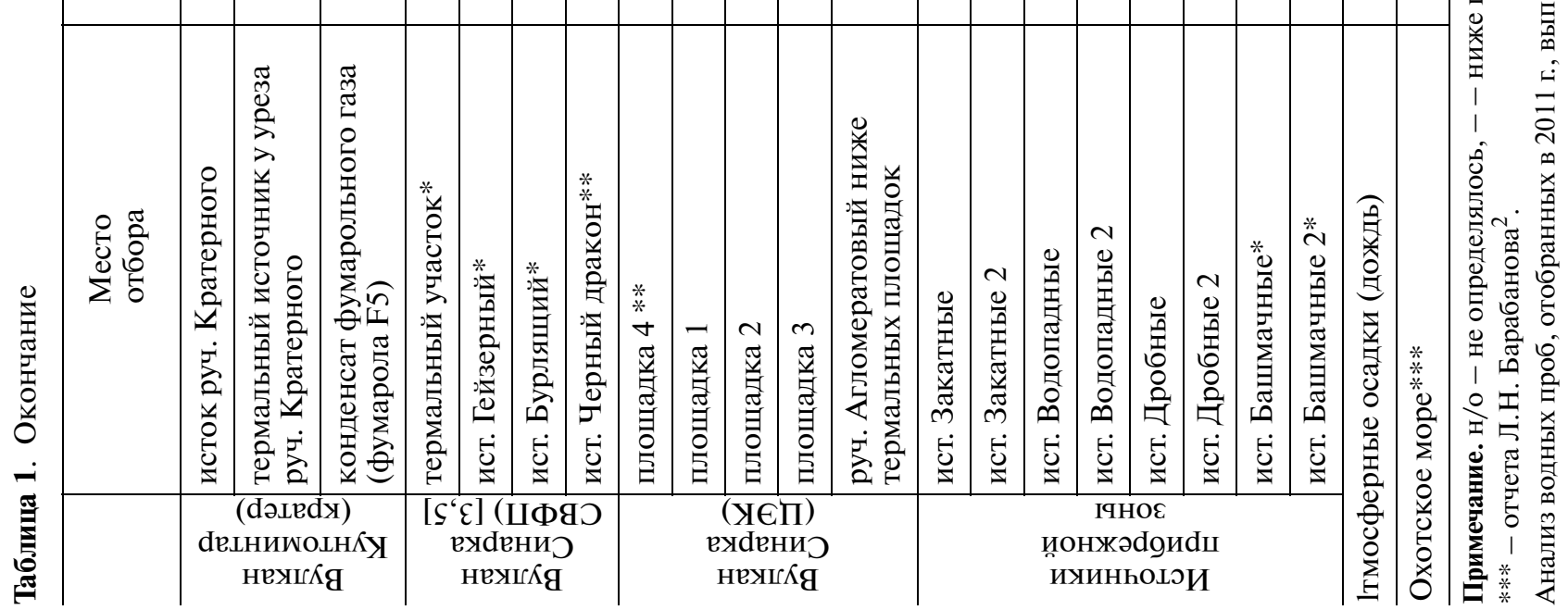



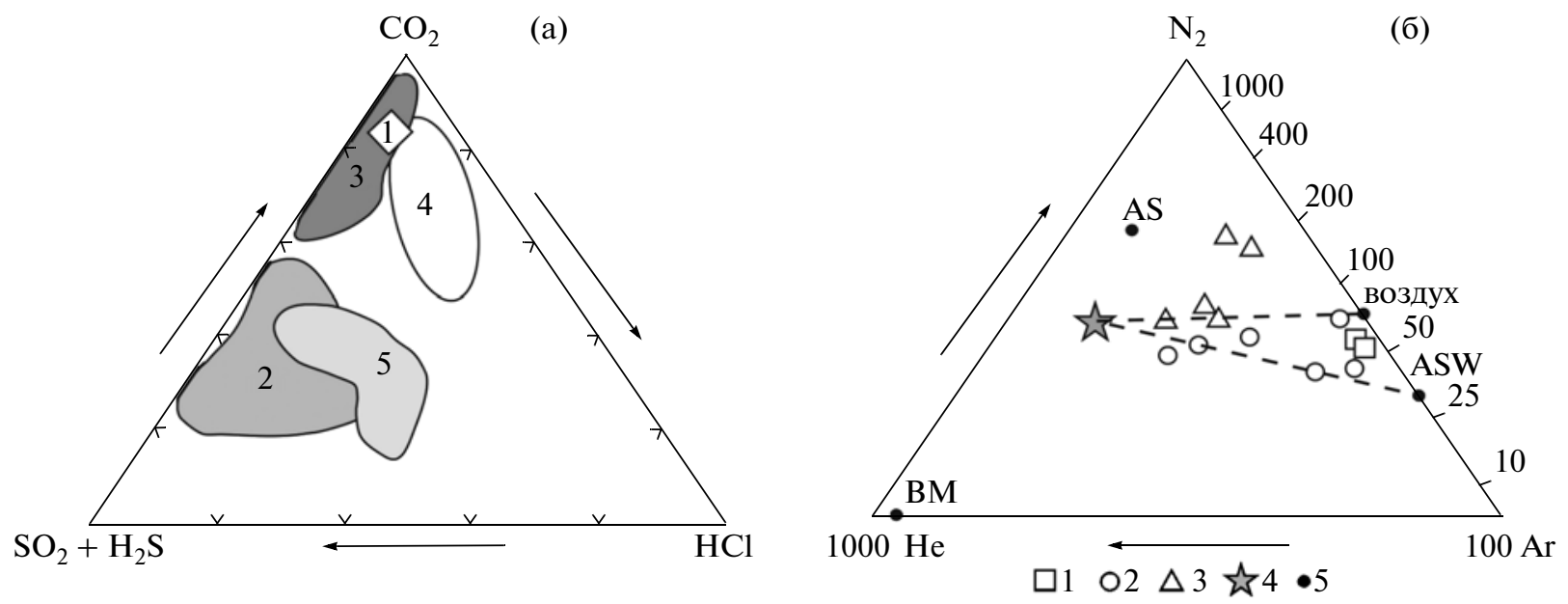

Рис. 3. Диаграммы газового состава: а - в координатах $\mathrm{CO}_{2}-\mathrm{HCl}-\left(\mathrm{SO}_{2}+\mathrm{H}_{2} \mathrm{~S}\right)$. Области ограничивают поля данных для: 1 - влк. Кунтоминтар, 2 - влк. Эбеко (Июльское фумарольное поле), 3 - влк. Остров Уайт по [Giggenbach, 1997], влк. Эбеко (Северо-Восточное фумарольное поле, кратеры), 4 - влк. Эбеко (Юго-Восточное фумарольное поле), 5 активных андезитовых вулканов по [Shinohara et al., 1993];

б - диаграмма Гиггенбаха [Shinohara et al., 1993] относительного содержания $\mathrm{N}_{2}-\mathrm{Ar}-\mathrm{He}: 1$ - влк. Кунтоминтар; 2 - влк. Эбеко (данные авторов), 3 - высокотемпературные газы андезитовых вулканов Японии [Shinohara et al., 1993], 4 - coстав первичного вулканического газа по [Shinohara et al., 1993], 5 - особые точки со значениями, характерными для: BM - базальта мантийного клина, AS - андезита зоны субдукции, ASW - насыщенной воздухом грунтовой воды [Shinohara et al., 1993].

Условия формирования термальных вод. По мнению [Мархинин, Стратула, 1977] источники прибрежной полосы формируются за счет смешения “восходящих перегретых потоков” с инфильтрационными водами морского происхождения в близповерхностных условиях. Эти перегретые потоки образуются вследствие частичной конденсации газосодержащих паров, выделяемых остывающими магматическими телами, находящимися на глубине непосредственно в районах источников. Химический состав источников кратера Кунтоминтар и Центрального экструзивного купола обусловлен растворением магматических газов в поверхностных или инфильтрационных водах. Источники Северо-Восточного поля вулкана Синарка формируются двумя путями: 1) за счет смешения сольфатарных газов со снеговыми или дождевыми водами, попадаюшими непосредственно в “котел"; 2) за счет попадания грунтовых вод в зону повышенных температур.

В отчете ${ }^{2}$ условия формирования подземных вод острова не рассматриваются, но отмечается, что источники Башмачные, Двуконусные, Водо- падные и Дробные, а также СВГП и термальные площадки ЦЭК являются поверхностными проявлениями Северо-Шиашкотанской гидротермальной системы, а термопроявления кратера вулкана Кунтоминтар, Закатные и Обвальные источники Кунтоминтарской гидротермальной системы.

Мы считаем, что эти два представления верны только частично и требуется уточнение вопросов, связанных, как с условиями формирования термальных вод, так и с приуроченностью тех или иных выходов к гидротермальным системам острова. Для этого необходимо определить источники водного и теплового питания, изучить, при каких температурах возможно формирования тех или иных типов термальных вод, классифицировать выделенные гидротермальные системы.

Сравнительный гидрохимический анализ термальных вод острова. Для определения основных черт сходства и различия в химическом составе исследуемых вод и выявления источников водного питания проведен сравнительный анализ всех групп терм. На графиках, показывающих связь между концентрациями отдельных макрокомпо-

Таблица 2. Средний состав фумарольного газа вулкана Кунтоминтар 24.06.2011, мол. \%

\begin{tabular}{c|c|c|c|c|c|c|c|c|c|c|c|c|c|c|c}
\hline \multirow{2}{*}{$T^{\circ} \mathrm{C}$} & \multirow{2}{*}{$\mathrm{H}_{2} \mathrm{O}$} & \multicolumn{7}{|c|}{ Бе $\mathrm{H}_{2} \mathrm{O}$} & \multirow{2}{*}{$\mathrm{S} / \mathrm{Cl}$} & $\mathrm{S} / \mathrm{C}$ & $\mathrm{CO}_{2} / \mathrm{H}_{2}$ \\
\cline { 3 - 14 } & & $\mathrm{CO}_{2}$ & $\mathrm{H}_{2} \mathrm{~S}$ & $\mathrm{SO}_{2}$ & $\mathrm{HCl}$ & $\mathrm{CO}$ & $\mathrm{CH}_{4}$ & $\mathrm{H}_{2}$ & $\mathrm{~N}_{2}$ & $\mathrm{O}_{2}$ & $\mathrm{Ar}$ & $\mathrm{He}$ & & & \\
\hline 480 & 98.24 & 80.309 & 9.298 & 7.812 & 0.415 & 0.00014 & 0.0012 & 0.0017 & 1.743 & 0.391 & 0.028 & 0.00017 & 37.48 & 0.21 & 49969 \\
\hline
\end{tabular}

Примечание. Анализ газовых проб выполнен в АЦ ИВиС ДВО РАН. Аналитики: В.Н. Шапарь, И.Ф. Тимофеева. 

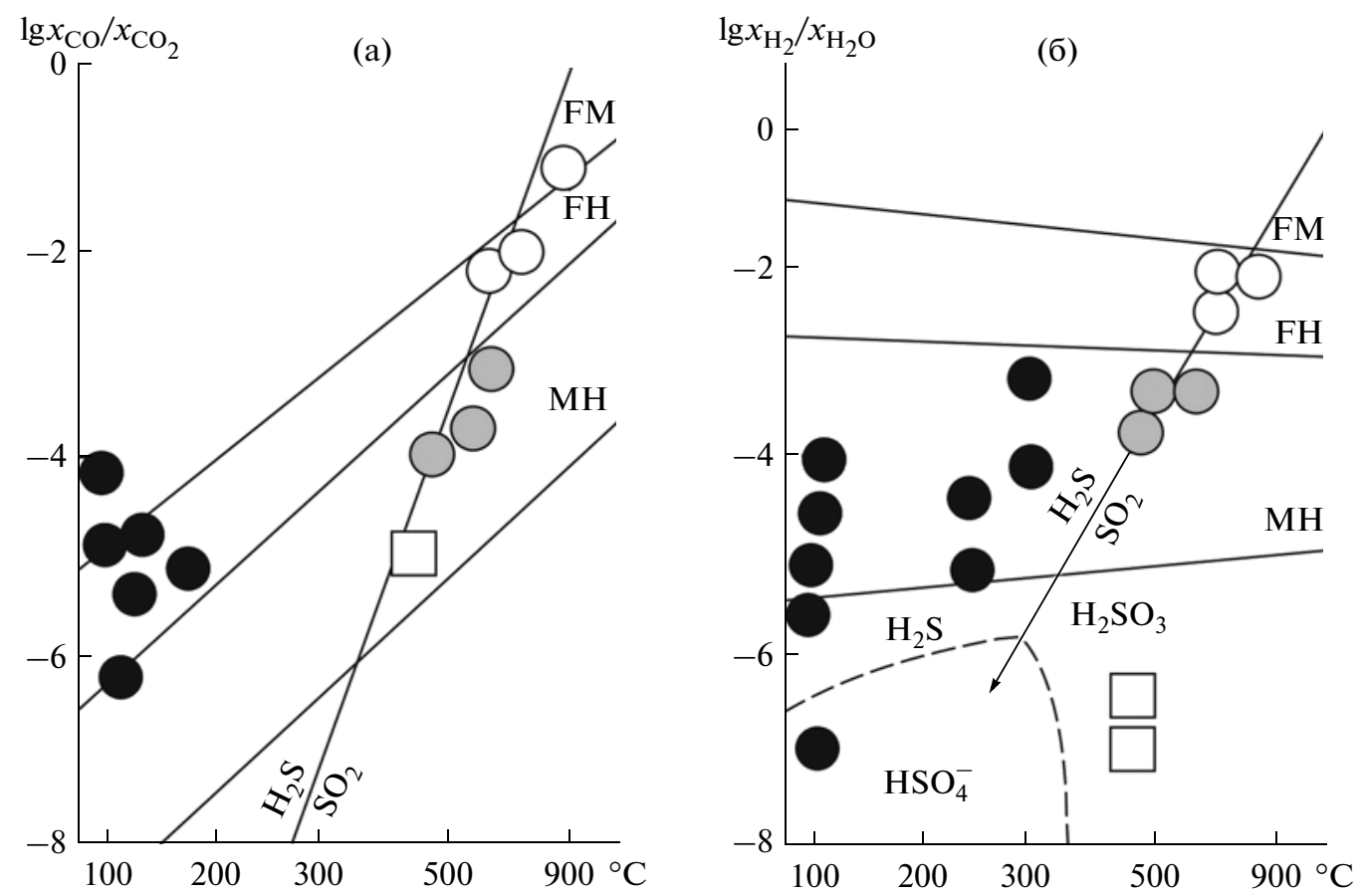

\begin{abstract}
$1 \bigcirc 2 \bigcirc 3 \bigcirc 4$
Рис. 4. Вариации значений редокс-отношений для фумарольных газов и вмещающих пород в зависимости от температуры на поверхности: 1 - влк. Кунтоминтар, 2 - влк. Момотомбо, влк. Кудрявый, влк. Августин по [Giggenbach, 1987], 3 - влк. Эбеко (данные авторов), 4 - влк. Остров Уайт, Папандаян по [Giggenbach, 1997], влк. Кудрявый по [Giggenbach, 1987]. Обозначения буферов: FM - файялит-магнетитовый, FH - файялит-гематитовый, MH - магнетит-гематитовый, $\mathrm{H}_{2} \mathrm{~S}-\mathrm{SO}_{2}$ - газовый изомоляльного сосуществования серных газов.
\end{abstract}

нентов (рис. 5), вынесены точки, отражающие значения, характерные для термальных вод, разгружающиеся на склонах вулкана Синарка (ЦЭК и СВГП) и в прибрежной зоне. Для сравнения на графиках показаны соотношения концентраций компонентов в фоновых водах (морская вода и атмосферные осадки в виде дождя) (см. табл. 1) и конденсате фумарольного газа вулкана Кунтоминтар. На графиках видно, что в термальных водах, разгружающихся на склонах вулкана Синарка, нет явной взаимосвязи между отдельными компонентами, тогда как для береговых терм характерна линейная зависимость между концентрациями основных катионов и анионов с высокими коэффициентами корреляции (0.8-0.99). При этом точки на графиках соотношений концентраций $\mathrm{K}-\mathrm{Na}, \mathrm{Mg}-\mathrm{Na}, \mathrm{Cl}-\mathrm{Na}, \quad \mathrm{SO}_{4}-\mathrm{Na}$ (см. рис. 5) расположены вдоль линии смешения морских и метеорных вод. Это указывает на определяющую роль доли морских вод при формировании термальных вод, разгружающихся в прибрежной зоне острова. Как показано в работе [Inguaggiato et al., 2000] небольшие отклонения от линии смешения в сторону увеличения калия (см. рис. 5д) и уменьшения магния (см. рис. 5е) характерны для морских вод, прошедших интенсивное взаимодействие с вмещающими породами и маг- матическими флюидами. По результатам численного моделирования взаимодействия морской воды с кислым, горячим и обогащенным $\mathrm{CO}_{2}$ глубинным флюидом [Inguaggiato et al., 2000] для гидротермальных систем островодужного типа по [Lawless, 1993] получается, что с увеличением температуры и давления и последующим уменьшением рН происходит значительное изменение исходного состава морской воды. Растворимость соединений кальция и магния с ростом температуры падает, в результате эти компоненты осаждаются из воды в виде карбонатов. Напротив, соединения калия и натрия имеют тенденцию увеличивать растворимость при росте температуры и уменьшении рН. Высокая степень корреляции между концентрациями отдельных компонентов в источниках береговой зоны указывают также на принадлежность их к одному водоносному горизонту.

Отношение $\mathrm{Cl} / \mathrm{B}$ (рис. 5в) в термальных водах обычно используется для решения задачи о происхождении и эволюции гидротерм в ходе смешения горячих и холодных вод [Arnorsson, Andresdottir, 1995] в зоне восходящего потока гидротермальной системы. На график (см. рис. 5в) нанесены точки, отражающие отношение концентраций этих компонентов в морской и ме- 

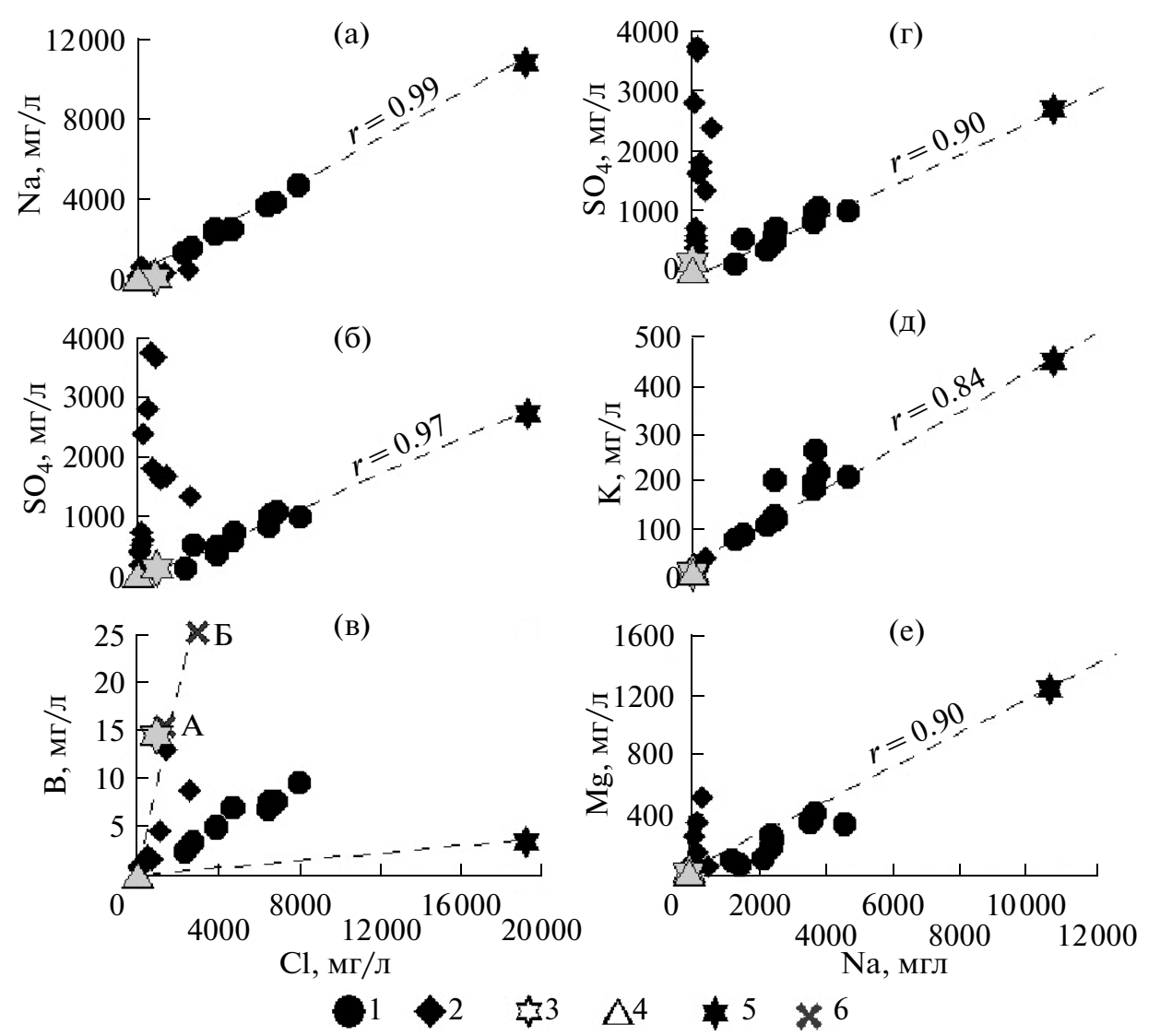

Рис. 5. Соотношение концентраций макрокомпонентов в термальных водах о. Шиашкотан.

1 - термальные источники прибрежной зоны; 2 - термальные источники склонов влк. Синарка; 3 - конденсат газа влк. Кунтоминтар; 4 - атмосферные осадки (дождь); 5 - морская вода; 6 - вмещающие породы: А - андезит, Б - базальт.

теорной водах, а также в вулканических породах, характерных для о. Шиашкотан. В воде Охотского моря вблизи острова содержится 3.4 мг/л бора и 19128 мг/л хлора (см. табл. 1), отношение $\mathrm{Cl} / \mathrm{B}=$ $=5680$. Дождевая вода имеет очень низкое содержание этих компонентов. Концентрация бора в атмосферных осадках ниже предела обнаружения, количество хлора составляет 2.13 мг/л. Основными породами, слагающими остров, являются андезиты и базальты. Для андезитов (А) характерно отношение $\mathrm{Cl} / \mathrm{B}=30$, а для базальтов (Б) $\mathrm{Cl} / \mathrm{B}=65$ [Arnorsson, Andresdottir, 1995; Inguaggiato et al., 2000]. Практически все точки, отражающие данные для различных типов исследуемых термальных вод, на графике занимают промежуточное положение между линиями, характеризующими смешение метеорных вод с морскими водами и вмещающими породами. Исключение составляет конденсат фумарольного газа из кратера вулкана Кунтоминатар, в котором отношение $\mathrm{Cl} / \mathrm{B}$ равно 61 , что близко к значениям, характерным для вмещающих пород. Полученные данные свидетельствуют о том, что химический состав термальных вод может формироваться за счет разной степени взаимодействия вмещающих пород с метеорными и морскими водами.

Температурный режим. Для предварительных оценок глубинных температур, при которых происходит формирование различных типов термальных вод исследуемого района, применены ионно-солевые геотермометры. Термальные воды, разгружающиеся в пределах острова, имеют невысокие дебиты, температуру меньше $100^{\circ} \mathrm{C}$. В расчетах использованы $\mathrm{Na} / \mathrm{K}$ - и $\mathrm{SiO}_{2}$-геотермометры (табл. 3).

Треугольная диаграмма относительных концентраций $\mathrm{Na}, \mathrm{K}$, и $\mathrm{Mg}$ (диаграмма Гиггенбаха) [Giggenbach, 1997] широко используется для выявления типов термальных вод, для которых воз-

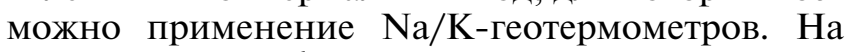
диаграмме (рис. 6) отражены точки, отражающие соотношение концентраций катионов, характерные для исследуемых источников. Точки, характеризующие термальные воды, разгружающиеся на склонах вулкана Синарка (ЦЭК и СВГП) и в кратере вулкана Кунтоминтар сконцентрированы в области “не зрелых вод”, по [Giggenbach, 1997]. 
Таблица 3. Измеренные и рассчитанные глубинные температуры термальных вод о. Шиашкотан

\begin{tabular}{|c|c|c|c|c|c|c|c|c|}
\hline \multirow{2}{*}{ Точка отбора пробы } & \multirow{2}{*}{$T,{ }^{\circ}$ Сизм } & \multicolumn{2}{|c|}{$\mathrm{SiO}_{2}-$ кварц } & \multicolumn{2}{|c|}{$\mathrm{SiO}_{2}$-халцедон } & \multirow{2}{*}{$\frac{\mathrm{Na} / \mathrm{K}}{\mathrm{N}}$} & \multirow{2}{*}{$\frac{\mathrm{Na} / \mathrm{K}}{\mathrm{T}}$} & \multirow{2}{*}{$\frac{\mathrm{Na} / \mathrm{K}}{\mathrm{A}}$} \\
\hline & & $\mathrm{F}$ & A & A & $\mathrm{F}$ & & & \\
\hline ист. Закатные & 53.4 & 118 & 117 & 93 & 91 & 187 & 183 & 175 \\
\hline ист. Дробные & 43.0 & 142 & 141 & 119 & 123 & 160 & 163 & 143 \\
\hline ист. Дробные 2 & 43.4 & 146 & 145 & 123 & 128 & 176 & 184 & 162 \\
\hline ист. Водопадные & 55.6 & 157 & 156 & 134 & 143 & 147 & 145 & 128 \\
\hline ист. Водопадные 2 & 63.8 & 157 & 156 & 134 & 143 & 151 & 150 & 133 \\
\hline площадка 1 (ЦЭК) & 51.2 & 186 & 186 & 167 & 185 & & & \\
\hline площадка 2 (ЦЭК) & 37.6 & 165 & 165 & 144 & 155 & & & \\
\hline площадка 3 (ЦЭК) & 42.6 & 161 & 161 & 139 & 149 & & & \\
\hline $\begin{array}{l}\text { термальный источник у уреза } \\
\text { руч. Кратерный }\end{array}$ & 64.5 & 193 & 193 & 174 & 194 & & & \\
\hline ист. Черный дракон (СВФП) & 93.1 & 112 & 110 & 109 & 111 & & & \\
\hline
\end{tabular}

Примечание. Авторы геотермометров: F - Fournier, 1977; A - Arnorsson et al., 1983; N - Nieva and Nieva, 1987; T - Tonani, 1980, данные из работы [Inguaggiato et al., 2000].

Такое расположение предполагает наличие растворов, агрессивных по отношению к вмещающим породам, а не установлению равновесия “вода-порода". Подобное состояние характерно для кислых термальных вод, формирующихся за счет смешения магматических эманаций с подземными водами в приповерхностных условиях. Следо-

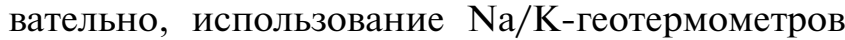
для таких вод не корректно.

Точки, отражающие значения относительных концентраций $\mathrm{Na}-\mathrm{K}-\mathrm{Mg}$ в термальных водах прибрежной зоны острова, находятся на границе частично равновесных и уравновешенных с породами вод, по [Giggenbach, 1997], в диапазоне температур от 120 до $180^{\circ} \mathrm{C}$ (см. рис. 3). Рассчитанные температуры по $\mathrm{Na} / \mathrm{K}$ геотермометрам для этих вод дают подобный интервал температур от 128 до $187^{\circ} \mathrm{C}$ (см. табл. 3). Вероятно, такой разброс связан с тем, что в итоговом химическом составе $\mathrm{Na}-\mathrm{Cl}$ термальных вод искажены истинные катионные отношения за счет смешения их с холодными грунтовыми водами в близповерхностных условиях.

Рассчитанные по $\mathrm{SiO}_{2}$-геотермометрам глубинные температуры также представлены в табл. 2. Для источников термального поля ЦЭК диапазон температур составляют $139-186^{\circ} \mathrm{C}$, для кратера вулкана Кунтоминтар - $174-194^{\circ} \mathrm{C}$, для источника "Черный дракон” СВГП $-109-112^{\circ} \mathrm{C}$. Глубинные температуры, рассчитанные по $\mathrm{SiO}_{2}$ геотермометрам для термальных источников прибрежной зоны ниже (см. табл. 3), чем полученные в результате использования $\mathrm{Na} / \mathrm{K}$-геотермометров. Можно предположить, что в процессе подъема гидротерм и в местах разгрузки на поверхности происходит осаждение кремнезема и его модификаций из раствора, что приводит к уменьшению концентрации растворенной кремнекислоты в зоне разгрузки. Многие водопроводящие трещины (в дайках и лавовых блоках) на всех термальных площадках прибрежной зоны, помимо других минералов, заполнены полосчатым кварцем и халцедоном.

Предварительные концептуальные модели генезиса гидротермальных систем. Основными факто-

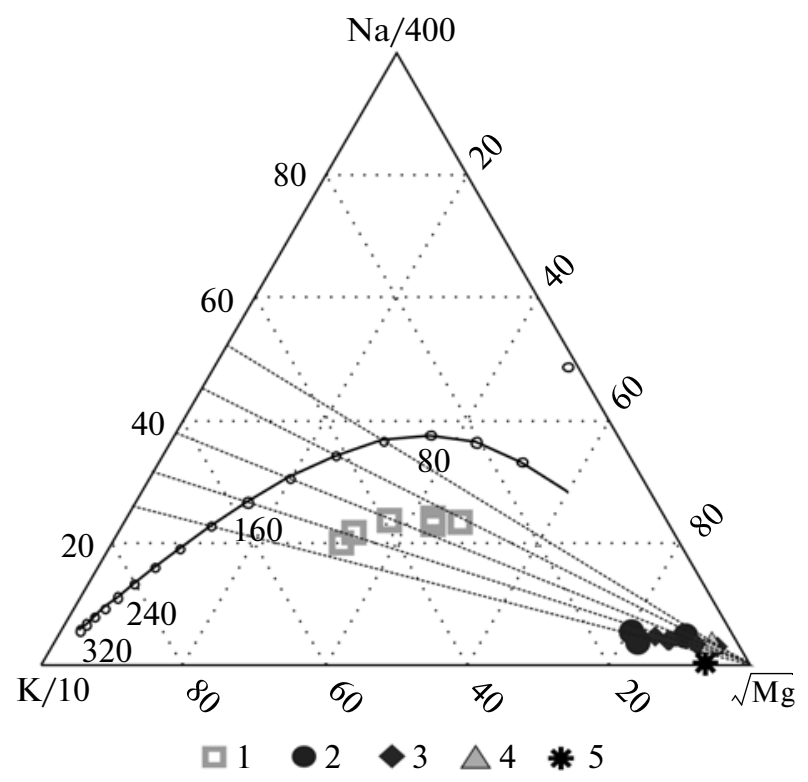

Рис. 6. Диаграмма относительных концентраций $\mathrm{Na}$, $\mathrm{K}$, и $\mathrm{Mg}$ для термальных вод по [Giggenbach, 1997]. 1 - термальные источники прибрежной зоны; 2 - Северо-Восточное гидросольфатарное поле (влк. Синарка); 3 - Термальное поле центрального экструзивного купола (влк. Синарка); 4 - термальные источники кратера влк. Кунтоминтар; 5 - конденсат газа влк. Кунтоминтар. 
рами, контролирующими природу гидротермальных систем, по [Lawless, 1993], являются: химический состав разгружающихся гидротерм и вмещающих пород и гидрогеологические условия малоглубинной части гидротермальных систем, обусловленные вулканотектоническими позициями и вулканогенными ландшафтами.

Преобладающими породами, развитыми на острове, являются андезиты. Вулканы, в недрах которых циркулируют гидротермы, имеют сложные постройки типа Сомма-Везувий, сильно разрушенные сейсмотектоническими обвалами (см. рис. 1). Особенности истории развития вулканов в голоценовый период привели к формированию различных гидрогеологических условий в северной и южной частях острова и образованию двух гидротермальных систем. Предварительная характеристика их заключается в следующем.

Северо-Шиашкотанская гидротермальная система является типичным примером гидротермальных систем островодужного типа [Lawless, 1993], связанных с активным андезитовым вулканизмом. Поверхностные термопроявления системы встречаются на протяжении 5-8 км зоны растека и имеют классическую вертикальную гидрохимическую зональность, характерную для гидротермальных систем вулканических дуг. Проекции восходящих гидротерм на дневной поверхности асимметричны. Условно их можно разделить на несколько потоков. В зоне основного восходящего потока, пространственно совпадающего с молодым экструзивным куполом вулкана Синарка, сконцентрирована мощная парогазовая деятельность. Температура фумарол на границе купола и молодого конуса в среднем составляет 100$150^{\circ} \mathrm{C}$, непосредственно на куполе достигает $449^{\circ} \mathrm{C}$ [Жарков и др., 2011]. У подножия экструзивного купола, на западном склоне вулкана на четырех термальных площадках происходит разгрузка кислых (рH < 4), сульфатно-хлоридных вод с пестрым катионным составом с общей минерализацией до 8 г/л и температурой до $60^{\circ} \mathrm{C}$, формирующихся в зоне аэрации за счет растворения фумарольных газов в инфильтрационных водах, дренирующих лавовые потоки экструзивного купола. Многочисленные парогазовые струи с температурой около $100^{\circ} \mathrm{C}$ и кипящие сульфатные и сульфатно-хлоридные источники с широким диапазоном значений рН и общей минерализацией до 1 г/л встречаются в бассейне ручья Серного. Приурочены они к вулкано-тектоническому разлому северо-восточного простирания [Мархинин, Стратула, 1977]. Их формирование также происходит в приповерхностных условиях. Пар и газ, в основном $\mathrm{CO}_{2}$ с примесью $\mathrm{H}_{2} \mathrm{~S}, \mathrm{SO}_{2}$, и возможно других газов, которые выделяются в глубинной части гидротермальной системы, по ослабленной зоне поднимаются к поверхности, где частично абсорбируется грунтовыми водами, насыщенными кислородом. В результате форми- руются разнообразные по химическому составу конденсатные воды, механизм формирования которых хорошо изучен и описан [Giggenbach, 1997; Arnorsson et al., 2007]. В прибрежной полосе разгружаются хлоридные натриевые термальные воды, являющиеся дериватами глубинных гидротерм, формирующихся в зоне восходящего потока гидротермальной системы. Места выходов их на поверхность контролируются пересечением разломов с дайковыми комплексами разных возрастов. На общие условия формирования термальных источников прибрежной зоны указывает их единый гидрохимический тип, высокая степень корреляции концентраций макрокомпонентов. Основным источником водного питания для глубинных гидротерм служат морские воды, поступающие в недра системы по зонам повышенной проницаемости, где они смешиваются с восходящим магматическим флюидом. В процессе миграции глубинного раствора к поверхности происходит смешение с холодными грунтовыми потоками, за счет чего происходит существенное снижение температуры на выходе гидротерм до $40-50^{\circ} \mathrm{C}$. Тепловое и газовое питание системы осуществляется, вероятнее всего, за счет больших объемов остывающих пород, находящихся на глубине и занимающих подводящий канал. Предполагаемая температура внутренней части тела купола на глубине составляет не менее 500-600 С [Стратула, 1969].

Поверхностные проявления Кунтоминтарской гидротермальной системы ограничены двумя термальными полями. Основная разгрузка осуществляется в виде мощных парогазовых струй в кратере молодого пирокластического конуса вулкана Кунтоминтар. Основываясь на проведенных геохимических исследованиях можно сделать вывод, что газы вулкана Кунтоминтар имеют магматическое происхождение: их конечный состав сформирован в результате подъема флюида к поверхности и значительного разбавления метеорной водой в близповерхностных условиях. Высокая температура газов на поверхности может быть объяснена тем, что вулкан находится в стадии активизации фумарольной деятельности. В пользу этого предположения свидетельствуют: ряд повышенных прогностических отношений $-\mathrm{S} / \mathrm{Cl}, \mathrm{S} / \mathrm{C}, \mathrm{CO}_{2} / \mathrm{H}_{2}-$ предикторов извержений для андезитовых вулканов [Меняйлов, 1976; Котенко и др., 2012] и появление нового термального участка.

\section{ЗАКЛЮЧЕНИЕ}

Полученные результаты геохимических исследований дают возможность скорректировать устоявшиеся представления об условиях формирования и разгрузки термальных вод острова Шиашкотан. Высказанное ранее [Мархинин, Стратула, 1977] предположение о том, что источники прибрежной зоны являются результатом смеше- 
ния в приповерхностных условиях восходящего перегретого потока, сформированного на глубине непосредственно под областью разгрузки, с инфильтрационными водами, ошибочно. Термальные воды, разгружающиеся на побережье острова, не могут существовать самостоятельно, а являются частью гидротермальной системы. В работе [Corbett, Leach, 1998], на основе исследований различных авторов, представлена характеристика гидротермальных систем островных дуг. Один из основополагающих тезисов заключается в том, что, в связи с недостаточным напором в глубинном хлоридном резервуаре, восходящие нейтральные хлоридные натриевые термы не достигают поверхности над зонами восходящих потоков. Рельеф в вулканических районах над зонами восходящих потоков расчлененный, с крутыми склонами. Следовательно, давление в резервуаре (газ + гидростатическое давление высокотемпературных гидротерм) не достаточно, чтобы преодолеть высокий гидростатический напор окружающих холодных подземных вод. В результате этого гидротермы растекаются латерально на 5-10 км вниз под уклон на более низкие отметки рельефа и их разгрузка контролируется уровнем моря. Схожая обстановка наблюдается в северной части о. Шиашкотан, где развита Северо-Шиашкотанская гидротермальная система. Высокая степень корреляции концентраций макрокомпонентов в водах термальных источников прибрежной зоны указывает на приуроченность их к одному водоносному горизонту. Следовательно, источники Закатные являются проявлениями Северо-Шиашкотанской гидротермальной системы, а не Кунтоминтарской, как предполагалось Барабановым².

Несмотря на то, что вулканы, в недрах которых циркулируют гидротермы, имеют схожие постройки типа Сомма-Везувий [Горшков, 1967], один и тот же вещественный состав и характеризуются активной сольфатарной деятельностью в привершинной части постройки, специфика их развития на последнем этапе формирования, связанная с кальдерообразованием на вулкане Кунтоминтар и образованием экструзивного купола на вулкане Синарка, привела к различным гидрогеологическим и геологическим условиям. В итоге, в недрах этих вулканических построек сформированы различные гидротермальные системы. Северо-Шиашкотанская гидротермальная система имеет классическую гидрохимическую зональность. Кунтоминтарская гидротермальная система носит локальный характер, поверхностные проявления ее ограничены двумя термальными полями. Высокая температура газов на поверхности и ряд повышенных прогностических отношений $\mathrm{S} / \mathrm{Cl}, \mathrm{S} / \mathrm{C}, \mathrm{CO}_{2} / \mathrm{H}_{2}$ в его составе свидетельствуют о возможной активизации фумарольной деятельности вулкана. Полученные нами результаты носят предварительный характер. Тре- буется проведение дальнейших исследований для уточнения генезиса термальных вод, разгружающихся в пределах острова Шиашкотан.

Авторы выражают благодарность В.Н. Бурканову, С.И. Архипову и В.Ш. Саакяну за неоценимую помощь, благодаря которой состоялась экспедиция на о. Шиашкотан в 2011 г.

Работа выполнена при финансовой поддержке грантов ДВО РАН 09-III А-08-423 и 11-ІІІ Д-08-044.

\section{СПИСОК ЛИТЕРАТУРЫ}

Атлас Сахалинской области. Хабаровск: ФГУП ДВ АГП, 2007. $107 \mathrm{c}$.

Горшков Г.С. Вулканизм Курильской островной дуги. М.: Наука, 1967. 287 c.

Жарков Р.В., Козлов Д.Н., Дегтерев А.В. Современная фумарольная и гидротермальная активность вулкана Синарка (о. Шиашкотан, Курильские острова) // Вестник КРАУНЦ. Науки о Земле. 2011. № 1. Вып. 17. C. 179-185.

Котенко Т.А., Котенко Л.В., Сандимирова Е.И. и др. Эруптивная активность вулкана Эбеко в 2010-2011 гг. (о. Парамушир) // Вестник КРАУНЦ. Науки о Земле. 2012. № 1. Вып. 19. С. 160-167.

Мархинин Е.К., Стратула Д.С. Новые данные о вулканах Центральных Курильских островов // Современный вулканизм. Т. І. М.: Наука, 1966. С. 94-98.

Мархинин Е.К., Стратула Д.С. Гидротермы Курильских островов. М.: Наука, 1977. 212 с.

Меняйлов И.А. Вулканические газы на различных стадиях вулканической активности // Гидротермальный процесс в областях тектоно-магматической активности. М.: Наука, 1976. С. 126-140.

Никитина Л.П., Меняйлов И.А., Шапарь В.Н. Модифицированные методы отбора и анализа фумарольных газов // Вулканология и сейсмология. 1989. № 4. С. 3-15.

Новейший и современный вулканизм на территории России / Отв. ред. Лаверов Н.П. М.: Наука, 2005. 604 с. Стратула Д.С. Вулканы и горячие источники о. Шиашкотан / Автореф. дис. ... канд. геол.-минерал. наук. Петропавловск-Камчатский, 1969. 20 с.

Федотов С.A. Оценки выноса тепла и пирокластики вулканическими извержениями и фумаролами по высоте их струй и облаков // Вулканология и сейсмология. 1982. № 4. С. 3-28.

Чирков А.М., Барабанов Л.Н., Башарина Л.А., Зеленов К.К. Состояние некоторых вулканов Курильских островов летом 1970 г. // Бюлл. вулканол. станций. М.: Наука, 1972. № 48. C. 33-39.

AquaChim 5.1. A Professional Application for Water Quality Data Analysis, Plotting, and Modeling. Waterloo Hydrogeologic, Inc. 2006. 366 p.

Arnorsson S., Andresdottir A. Processes controlling the distribution of boron and chlorine in natural waters in Iceland // Geochim. et Cosmochim. Acta. 1995. V. 59. P. 4125-4146.

Arnorsson S., Stefansson A., Bjarnason J.O. Fluid-fluid interactions in geothermal systems // Rev. Mineral. Geochem. 2007. V. 65. P. 259-312. 
Corbett G.J., Leach T.M. Southwest Pacific Rim Gold-Copper systems: Structure, Alteration and Mineralization // Special Pub. Society of Econ. Geol. Ins.1998. № 6. 237 p. Giggenbach W.F. Redox processes governing the chemistry of fumarolic gas discharges from White Island, New Zealand // Appl. Geochem. 1987. V. 2. P. 143-161.

Giggenbach W.F. The origin and evolution of fluids in magmatic-hydrothermal systems // Geochemistry of hydrothermal ore deposits (3-rd edition). New York, 1997. P. 737-796.

Giggenbach W.F., Garcia N.P., Londono A.C. et al. The chemistry of fumarolic vapor and thermal spring discharges from the Nevado del Ruiz volcanic-magmatic-hydrothermal system. Colombie // JVG. 1990. V. 42. P. 13-39.
Inguaggiato S., Pecoraino G., D'Amore F. Chemical and isotopical characterization of fluid manifestations of Isshia Island // J. of Volcanol. and Geotherm. Res. 2000. V. 99. P. $151-178$.

Lawless J.V. Variations in tapes of geothermal system with geological setting around the Pacific Rim // Islands and basins: correlation and comparison of onshore and offshore geology. SOPAC Miscellaneous Report. 1993. 22 p.

Shinohara H., Giggenbach W.F., Kazahya K., Hedenquist J.W. Geochemistry of volcanic gases and hot springs of Satsuma-Iwojima, Japan; Following Matsuo // Geochemical Jornal. 1993. V. 27. P. 271-285.

\title{
THE GEOCHEMISTRY OF THERMAL WATERS AND FUMAROLIC GASES ON SHIASHKOTAN I., KURIL ISLANDS
}

\author{
E. G. Kalacheva, T. A. Kotenko, L. V. Kotenko, and E. V. Voloshina \\ Institute of Volcanology and Seismology, Far East Branch, Russian Academy of Sciences, \\ Bul. Piipa 9, Petropavlovsk-Kamchatskii, 683006 Russia \\ e-mail:keg@kscnet.ru \\ Received April 24, 2013
}

\begin{abstract}
Based on geochemical studies we have updated our knowledge of the generation conditions and discharge of thermal waters on Shiashkotan Island. The thermal springs, which are abundant on the island, are surface expressions of the North Shiashkotan and Kuntomintar hydrothermal systems. The North Shiashkotan hydrothermal system shows the classical hydrochemical zonality. The discharge of the Kuntomintar hydrothermal system is confined within two thermal fields that are situated in the central and northeastern craters of the eponymous volcano. The high temperature of the gases that are issuing from Kuntomintar Volcano to the ground surface and the higher predictive ratios $\mathrm{S} / \mathrm{Cl}, \mathrm{S} / \mathrm{C}$, and $\mathrm{CO}_{2} / \mathrm{H}_{2}$ in its composition provide evidence of a possible renewal of its fumarole activity.
\end{abstract}

